\title{
Release of Sulfur and Chlorine during Cofiring RDF and Coal in an Internally Circulating Fluidized Bed
}

\author{
Xiaolin Wei,,${ }^{\dagger}{ }^{\dagger}$ Yang Wang, ${ }^{\dagger}$ Dianfu Liu ${ }^{\dagger}$ Hongzhi Sheng, ${ }^{\dagger}$ Wendong Tian, ${ }^{\dagger}$ and \\ Yunhan Xiao \\ Institute of Mechanics, and Institute of Engineering Thermophysics, Chinese Academy of Sciences, \\ Beijing 100190, China
}

Received June 18, 2008. Revised Manuscript Received October 17, 2008

\begin{abstract}
An internally circulating fluidized bed (ICFB) was applied to investigate the behavior of chlorine and sulfur during cofiring RDF and coal. The pollutant emissions in the flue gas were measured by Fourier transform infrared (FTIR) spectrometry (Gasmet DX-3000). In the tests, the concentrations of the species CO, $\mathrm{CO}_{2}$, $\mathrm{HCl}$, and $\mathrm{SO}_{2}$ were measured online. Results indicated when cofiring $\mathrm{RDF}$ and char, due to the higher content of chlorine in $\mathrm{RDF}$, the formation of $\mathrm{HCl}$ significantly increases. The concentration of $\mathrm{SO}_{2}$ is relatively low because alkaline metal in the fuel ash can absorb $\mathrm{SO}_{2}$. The concentration of $\mathrm{CO}$ emission during firing pure $\mathrm{RDF}$ is relatively higher and fluctuates sharply. With the $\mathrm{CaO}$ addition, the sulfur absorption by calcium quickly increases, and the desulfuration ratio is bigger than the dechlorination ratio. The chemical equilibrium method is applied to predict the behavior of chlorine. Results show that gaseous $\mathrm{HCl}$ emission increases with increasing $\mathrm{RDF}$ fraction, and gaseous $\mathrm{KCl}$ and $\mathrm{NaCl}$ formation might occur.
\end{abstract}

\section{Introduction}

Municipal solid waste (MSW) comprises combustibles (e.g., plastic, paper, textile, etc.), biomass with high moisture content (e.g., kitchen waste and wood, etc.), and noncombustibles (e.g., brick, ash, metal, etc.). According to the economical analysis, a hopeful treatment method of gaining maximum income is MSW integrating disposal technology, by which the three sorts of waste are disposed separately, that is, combustibles used to incinerate, biomass to compost, and noncombustibles to landfill or recycle. In this process of MSW disposal, combustibles are made as refuse-derived fuels (RDF), kitchen waste as fertilizer, and metal as recycling matter. This may bring considerable profits for an integrating disposal plant. Therefore, now such MSW disposal plants are being built in China. The production of RDF is growing as a potential fuel, and the pollution from RDF combustion should be a concern.

RDF has the advantage of high heating value and is easy to burn. One of the potential applications of RDF is cofiring with coal instead of some coal in the boiler. The faction of RDF in fuels has shared a $5-40 \%$ heating value in some boilers. ${ }^{1-3}$ Because of the high content of volatiles in RDF (more than $70 \%$ ), a large quantity of volatiles will release during RDF incineration, which is likely to cause unburnout of gaseous matters and induce the emissions (e.g., $\mathrm{CO}$ and dioxin) to exceed the environmental standard. The emissions (e.g., $\mathrm{CO}, \mathrm{SO}_{2}$, and $\mathrm{NO}_{x}$ ) of pollutants, PCDDs/Fs, and heavy metals have been

* To whom correspondence should be addressed. Telephone: +86-1082544231. Fax: +86-10-62561284. E-mail: xlwei@imech.ac.cn.

$\dagger$ Institute of Mechanics.

$¥$ Institute of Engineering Thermophysics.

(1) Norton, G. A.; Levine, A. D. Co-combustion of refuse-derived fuel and coal. Environ. Sci. Technol. 1989, 23, 774-783.

(2) Manninen, H.; Peltola, K.; Ruuskanen, J. Co-combustion of refusederived and packaging-derived fuels (RDF and PDF) with conventional fuels. Waste Manage. Res. 1997, 15, 137-147.

(3) Marton, C.; Alwast, H. Report: Operational experiences and legal aspects of co-combustion in Germany. Waste Manage. Res. 2002, 20, 476-483. investigated and evaluated..$^{4-11}$ Results show that, as compared to firing pure waste, cofiring may reduce the concentration of emissions.

In coal, the content of chlorine is very low, but for RDF, the content of chlorine normally is higher. The ash compositions (Table 1) of coal and RDF are very different, and the content of alkali or alkali earth metals in RDF normally is very high. During cofiring RDF and coal, the behavior of chlorine and sulfur will be determined by the formation of gaseous $\mathrm{HCl}$ and $\mathrm{SO}_{2}$ and retention of chlorine and sulfur in ash. In general, $\mathrm{HCl}$ emitted from a combustion process is the third important contribution to the global acidification from human activities (after $\mathrm{SO}_{x}$ and $\mathrm{NO}_{x}$ ). Chlorine and sulfur can also combine with alkali or alkaline-earth metals, which are likely to form aerosols

(4) Frankenhaeuser, M.; Hiltunen, M.; Manninen, H.; Palonen, J.; Ruuskanen, J.; Vartiainen, T. Emissions from co-combustion of used packaging with peat and coal. Chemosphere 1994, 29, 2057-2066.

(5) Lu, R.; Purushothama, S.; Yang, X.; Hyatt, J.; Pan, W.-P.; Riley, J. T.; Lloyd, W. G. TG/FTIR/MS study of organic compounds evolved during the co-firing of coal and refuse-derived fuels. Fuel Process. Technol. 1999, 59, 35-50.

(6) Li, H.; Yang, X.; Tomes, W.; Pan, W.-P.; Riley, J. T. Chlorinated organic compounds evolved during the combustion of blends of refusederived fuels and coals. J. Therm. Anal. 1997, 49, 1417-1422.

(7) Huotari, J.; Vesterinen, R. PCDD/F emissions from co-combustion of RDF with peat, wood waste, and coal in FBC boilers. Hazard. Waste Hazard. Mater. 1996, 13, 1-10.

(8) Gullett, B. K.; Dunn, J. E.; Bae, S. K.; Raghunathanet, K. Effects of combustion parameters on polychlorinated dibenzodioxin and dibenzofuran homologue profiles from municipal waste and coal co-combustion. Waste Manage. 1998, 18, 473-483.

(9) Yan, J. H.; Chen, T.; Li, X. D.; Zhang, J.; Lu, S. Y.; Ni, M. J.; Cen, K. F. Evaluation of PCDD/Fs emission from fluidized bed incinerators cofiring MSW with coal in China. J. Hazard. Mater. 2006, 135, 47-51.

(10) Manninen, H.; Perkio, A.; Palonena, J.; Peltola, K.; Ruuskanenet, J. Trace metal emissions from co-combustion of refuse derived and packaging derived fuels in a circulating fluidized bed boiler. Chemosphere 1996, 32, 2457-2469.

(11) Kouvo, P.; Backman, R. Estimation of trace element release and accumulation in the sand bed during bubbling fluidised bed co-combustion of biomass, peat, and refuse-derived fuels. Fuel 2003, 82, 741-753. 


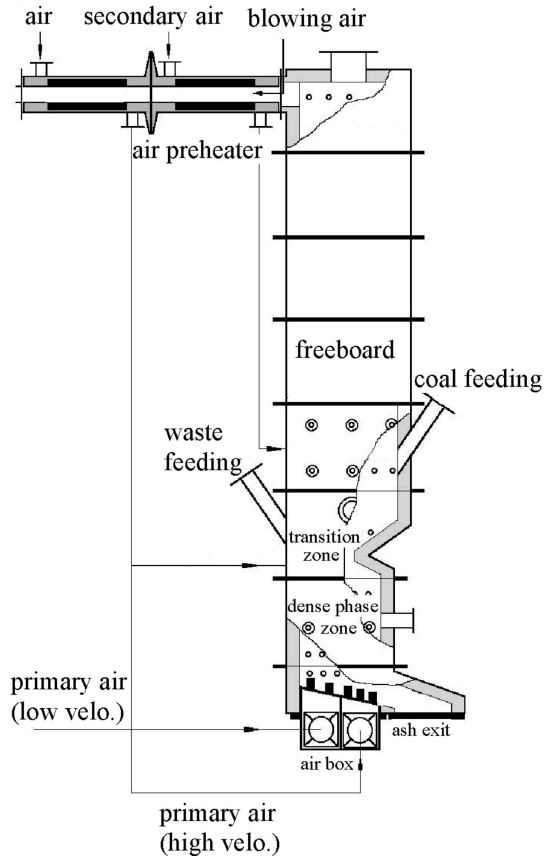

Figure 1. Schematic combustor of the internally circulating fluidized bed (ICFB).

in the flue gas. ${ }^{12,13}$ Also, the condensed matters are very harmful in terms of causing fouling, slagging, and high temperature corrosion in the furnace. ${ }^{14,15} \mathrm{In}$ addition, $\mathrm{HCl}$ and $\mathrm{SO}_{2}$ are known to catalyze the recombination of radicals in the flame and thus to inhibit the $\mathrm{CO}$ oxidation and affect the $\mathrm{NO}_{x}$ formation. ${ }^{16-19}$ $\mathrm{Cl}_{2}$ or $\mathrm{Cl}$ emitted from chlorine-containing fuel is also an important factor to form the dioxins. ${ }^{20,21} \mathrm{Up}$ to now, the study is still limited on the release of chlorine and sulfur for cofiring RDF and coal. Therefore, in the present article, the internally circulating fluidized bed (ICFB) was applied to investigate the behavior of chlorine and sulfur during cofiring RDF and coal.

\section{Experimental Section}

Figure 1 illustrates the schematic of the internally circulating fluidized bed incinerator. The fluidized air enters the bed via

(12) Fernandez, A.; Wendt, J. O. L.; Wolski, N.; Hein, K. R. G.; Wang, S.; Wittenet, M. L. Inhalation health effects of fine particles from the cocombustion of coal and refuse derived fuel. Chemosphere 2003, 51, 11291137.

(13) Lind, T.; Kauppinen, E. I.; Hokkinen, J.; Jokiniemi, J. K.; Orjala, M.; Aurela, M.; Hillamo, R. Effect of chlorine and sulfur on fine particle formation in pilot-scale CFBC of biomass. Energy Fuels 2006, 20, 61-68.

(14) Liu, K.; Xie, W.; Li, D.; Pan, W.-P.; Riley, J. T.; Riga, A. The effect of chlorine and sulfur on the composition of ash deposits in a fluidized bed combustion system. Energy Fuels 2000, 14, 963-972.

(15) Hansen, L. A.; Frandsen, F. J.; Dam-Johansen, K.; Sørensen, H. S.; Skrifvars, B.-J. Characterization of ashes and deposits from high-temperature coal-straw co-firing. Energy Fuels 1999, 13, 803-816.

(16) Westbrook, C. K. Inhibition of hydrocarbon oxidation in laminar flames and detonations by halogenated compounds. Nineteenth Symposium (Int.) on Combustion; The Combustion Institute, Pittsburgh, PA, 1982; pp $127-141$.

(17) Tseregounis, S.; Smith, O. I. An experimental investigation of fuel sulfur-fuel nitrogen interactions in low-pressure premixed flames. Twentieth Symposium (Int.) Combustion; The Combustion Institute, Pittsburgh, PA, 1985; pp 761-768.

(18) Wei, X.; Han, X.; Schnell, U.; Maier, J.; Wörner, H.; Hein, K. R. G. The effect of $\mathrm{HCl}$ and $\mathrm{SO}_{2}$ on $\mathrm{NO}_{x}$ formation in coal flames. Energy Fuels 2003, 17, 1392-1398.

(19) Wei, X.; Schnell, U.; Han, X.; Hein, K. R. G. Interactions of CO, $\mathrm{HCl}$, and $\mathrm{SO}_{x}$ in pulverised coal flames. Fuel 2004, 83, 1227-1233.

(20) Gullett, B. K.; Bruce, K. R.; Beach, L. O.; Drago, A. M. Mechanistic steps in the production of PCDD and PCDF during waste combustion. Chemosphere 1992, 25, 1387-1392.

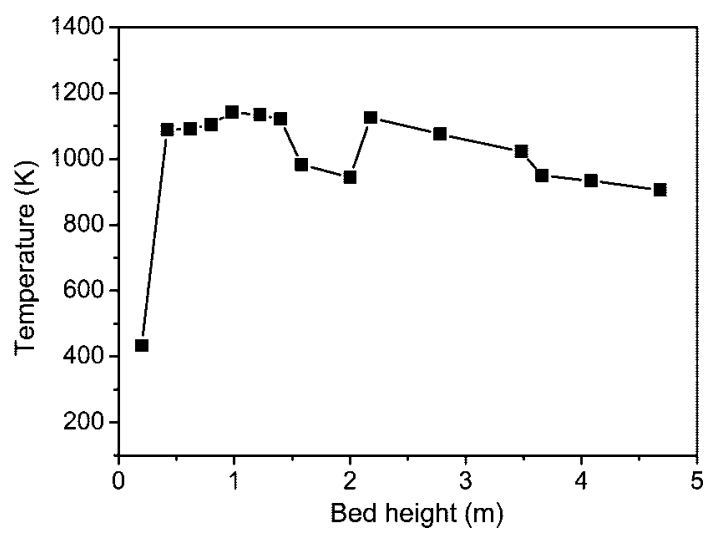

Figure 2. Gas temperature profile along the bed height during pure RDF combustion.

bubbling caps $(0.6 \%$ orifice coefficient). Under the inclined air distributor, the plenum is separated into two equal parts. Next, the primary air separately enters the bed from air boxes with high or low air velocity. Unevenly distributed fluidized air induces a largesize internally circulating flow of solid particle in the dense bed, which may improve the properties of lateral diffusion. ${ }^{22,23}$ Particles under the high air velocity move upward sharply and form the fluidization zone, whereas particles under the low air velocity move downward slowly and form the moving bed. The cross section of the dense phase zone is $500 \times 240 \mathrm{~mm}$, and the height is 1000 $\mathrm{mm}$. In the furnace, the dense phase zone changes gradually into the freeboard with the cross section of $800 \times 280 \mathrm{~mm}$ and the height of $3500 \mathrm{~mm}$. Sand is used as bed materials, and the particle diameter is $0.5-1.0 \mathrm{~mm}$. The air velocity is $6.0 u_{\mathrm{mf}}$ in the fluidized zone with high air velocity ( $u_{\mathrm{mf}}$ is minimum fluidized velocity) and $2.5 u_{\mathrm{mf}}$ in the moving zone with low air velocity. The feeding rate of fuel was about $5-15 \mathrm{~kg} / \mathrm{h}$. During cofiring RDF and coal, the oxygen content in flue gas is $6-8 \%$. During cofiring RDF and char, the oxygen content in flue gas is $10-16 \%$.

Figure 2 indicates the gas temperature profile along the bed height during pure RDF combustion. In the tests, the temperature is $1123-1173 \mathrm{~K}$ in the dense phase zone and decreases in the freeboard. The temperature is $923-1073 \mathrm{~K}$ at the exit. When cofiring coal or char with RDF, the bed temperature increases (sometimes to $1250 \mathrm{~K}$ ), but the temperature in the freeboard decreases because of the less volatile content in blending fuel. Normally, char combustion mostly occurs in the bed, and volatile combustion occurs in the freeboard. When firing pure char, the temperature was $1123-1223 \mathrm{~K}$ in the dense phase zone and decreases in the freeboard. The temperature was $523-573 \mathrm{~K}$ at the exit.

When the fluidized bed is started up, first the bed is heated to about $673 \mathrm{~K}$ by the ignition of wood with oil. Next, the fine coal $(<1 \mathrm{~mm})$ is added to heat the bed to $873-973 \mathrm{~K}$. Finally, coal particle is added until the bed temperature rises to about $1173 \mathrm{~K}$. After the combustion is stabilized for 20-30 min, the test will begin, which will last for 30-60 min. Although two small heat transfer tubes are immersed into the sand bed, the bed temperature is mainly controlled by the balance between the heat release from burning fuel and the heat loss from gas and wall. Therefore, sometimes, a higher excess air has to be used to ensure that enough heat can be carried out by the flue gas.

A sampling probe is installed at the flue gas exit near the top of the furnace. The temperature of the sampling tube lines is heated

(21) Tuppurainen, K.; Halonen, I.; Ruokojärvi, P.; Tarhanen, J.; Ruuskanen, J. Formation of PCDDs and PCDFs in municipal waste incineration and its inhibition mechanisms: A review. Chemosphere 1998, 36, 14931511.

(22) Saito, H.; Kosugi, S.; Sato, K. The revolving-type fluidized-bed incinerator-its basic performance in MSW combustion. Waste Manage. Res. 1988, 6, 261-270.

(23) Sheng, H.-Z.; Wei, X.-L.; Li, J.; Tian, W.-D.; Jin, J.; Jiang, H.-A.; Cao, J.-B.; Gao, J. The heat transfer study of external super-heater of CFB incinerator. Environ. Eng. Sci. 2004, 21, 39-44. 
Table 1. Ash Composition

\begin{tabular}{|c|c|c|c|c|c|c|c|c|c|}
\hline \multirow[b]{2}{*}{ fuel } & \multicolumn{9}{|c|}{ ash basis (wt \%) } \\
\hline & $\mathrm{SiO}_{2}$ & $\mathrm{P}_{2} \mathrm{O}_{5}$ & $\mathrm{CaO}$ & $\mathrm{K}_{2} \mathrm{O}$ & $\mathrm{Na}_{2} \mathrm{O}$ & $\mathrm{MgO}$ & $\mathrm{Al}_{2} \mathrm{O}_{3}$ & $\mathrm{Fe}_{2} \mathrm{O}_{3}$ & $\mathrm{TiO}_{2}$ \\
\hline RDF & 43.6 & 5.0 & 13.11 & 6.1 & 9.11 & 7.74 & 8.76 & 7.29 & \\
\hline coal & 58.72 & 0.22 & 2.7 & 2.05 & 0.12 & 0.54 & 21.26 & 11.22 & 0.84 \\
\hline
\end{tabular}

Table 2. Fuel Properties

\begin{tabular}{|c|c|c|c|c|c|c|c|c|c|c|c|}
\hline \multirow[b]{2}{*}{ fuel } & \multicolumn{5}{|c|}{ chemical analysis (wt \%, dry basis) } & \multicolumn{6}{|c|}{ ultimate analysis (wt \%, dry basis) } \\
\hline & moisture $^{a}$ & volatile & carbon & ash & $Q_{\text {net }}^{b}$ & $\mathrm{C}$ & $\mathrm{H}$ & $\mathrm{O}$ & $\mathrm{N}$ & $\mathrm{S}$ & $\mathrm{Cl}$ \\
\hline RDF & 0 & 73.48 & 9.35 & 17.17 & 24.10 & 57.24 & 9.09 & 14.39 & 0.21 & 0.26 & 1.64 \\
\hline coal & 7.82 & 29.23 & 58.58 & 12.19 & 28.20 & 71.41 & 4.03 & 11.20 & 0.90 & 0.27 & 0.007 \\
\hline char & 11.0 & 1.94 & 84.19 & 13.87 & 25.03 & 83.63 & 0.36 & 0.80 & 0.74 & 0.61 & 0.07 \\
\hline
\end{tabular}

${ }^{a}$ As arrived. ${ }^{b}$ Lower heating value, unit: $\mathrm{MJ} / \mathrm{kg}$.

to $453 \mathrm{~K}$. Concentrations of pollutants in the flue gas were measured by Fourier transform infrared (FTIR) spectrometry (Gasmet DX3000). In the tests, the concentrations of species $\mathrm{H}_{2} \mathrm{O}, \mathrm{CO}, \mathrm{CO}_{2}$, $\mathrm{NO}, \mathrm{N}_{2} \mathrm{O}, \mathrm{HCl}$, and $\mathrm{SO}_{2}$ may be measured online with $2 \%$ error. The concentration of oxygen was measured by oxygen analyzer (TEMET 19) with $0.2 \%$ error.

Table 2 shows the fuel properties, including RDF, bituminous coal, and char. Because waste is fully dried in the process of $\mathrm{RDF}$, almost no water is contained in RDF. The lower heating value of RDF is similar to that of the char. In Table 2, the content of hydrogen, oxygen, and chlorine in RDF is extremely higher than that in coal or char. The higher hydrogen and oxygen content occurs because of the organic matters in waste. Also, the higher chlorine content arises from chlorine in PVC (polyvinyl chloride) plastic and waste paper as well as from salt in food. The shape of RDF is a small rod with a diameter of 15 $\mathrm{mm}$ and length of $30-45 \mathrm{~mm}$. The diameter of coal or char is in the range of $0.5-15 \mathrm{~mm}$.

\section{Results}

Figures 3, 4, and 5 show the concentration of $\mathrm{HCl}, \mathrm{SO}_{2}$, or $\mathrm{CO}$ with varied time during pure RDF combustion (feeding $15 \mathrm{~kg} / \mathrm{h} \mathrm{RDF}$ ). Because of the higher chlorine content in RDF, $\mathrm{HCl}$ concentration increases gradually with RDF addition. The range of $\mathrm{HCl}$ concentration is from 600 to $800 \mathrm{mg} / \mathrm{m}^{3}$, and the variation ratio is less than $28 \%$ of the average value. However, the concentration of $\mathrm{SO}_{2}$ or $\mathrm{CO}$ significantly varies, and the biggest variation ratio is $63 \%$ for $\mathrm{SO}_{2}$ and $97 \%$ for $\mathrm{CO}$ emission. The average concentrations of $\mathrm{SO}_{2}$ and $\mathrm{CO}$ are $152 \mathrm{mg} / \mathrm{m}^{3}$ and $0.24 \%$, respectively. Because of the very high volatile content $(73 \%)$ in $\mathrm{RDF}$, most gas combustion occurs in the freeboard.

In ICFB, air with high or low velocity enters the different bed zone. Gas velocity above the high velocity zone is also very high and the oxygen is insufficient in the low velocity zone, and this will affect the gas mixing in the freeboard. The poor gas mixing will inhibit the $\mathrm{CO}$ oxidation.

The results also indicate the pollutant emissions are significantly influenced by the various bed temperatures, the residence time, and fuel property. During data processing, we use the average value of data with varied time in the relatively stable condition.

Figures 6-9 indicate concentrations of $\mathrm{SO}_{2}, \mathrm{HCl}, \mathrm{CO}$, and $\mathrm{NO}$ during cofiring RDF and char or coal. In Figure $6, \mathrm{SO}_{2}$ emission decreases with increasing RDF fraction because of lower sulfur content in RDF than in char. During cofiring RDF and coal, although the sulfur content in RDF is similar to that in coal, the curve of $\mathrm{SO}_{2}$ in Figure 6 rises slightly with increasing RDF fraction. During cofiring RDF and char, due to higher chlorine content in RDF, the concentration of $\mathrm{HCl}$ approximately linearly varies with increasing RDF fraction in Figure 7. Because the volatile content in RDF is much bigger than that in char and coal, the CO concentration in Figure 8 gradually increases with increasing RDF fraction. Generally, the carbon in char or coal is mainly burned in the bed, but the volatile in RDF is combusted in the freeboard. During cofiring RDF and coal, the bed is fed more amount of fuel $(15 \mathrm{~kg} / \mathrm{h})$ than that during cofiring RDF and char $(<7.5$ $\mathrm{kg} / \mathrm{h}$ ), and a lot of volatile is released into the freeboard and cannot be oxidized completely in time. Thus, $\mathrm{CO}$ emission is higher in cofiring RDF and coal. Figure 9 indicates the release of NO during cofiring RDF and char. NO emission increases with increasing RDF fraction. Obviously, the nitrogen in RDF may be transformed preferably as NO despite the higher nitrogen content in char.

Figures 10 and 11 indicate gaseous $\mathrm{SO}_{2}$ and $\mathrm{HCl}$ conversion ratio during co-combustion with various RDF fractions. With increasing RDF ratio, the gaseous $\mathrm{SO}_{2}$ conversion ratio slightly increases, and the $\mathrm{HCl}$ conversion ratio obviously decreases.

In the tests, pulverized $\mathrm{CaO}$ is added to absorb sulfur and chlorine during pure RDF combustion. Figures 12 and 13 give the desulfuration and dechlorination ratio with $\mathrm{CaO}$ addition. With increasing $\mathrm{Ca} /(\mathrm{S}+0.5 \mathrm{Cl})$ ratio, the sulfur absorption by calcium may quickly increase. When the $\mathrm{Ca} /$ $(\mathrm{S}+0.5 \mathrm{Cl})$ ratio attains 2.5 , the desulfuration ratio will keep stable at about $82 \%$. As compared to the desulfuration ratio, the chlorine absorption by calcium steadily increases with increasing $\mathrm{Ca} /(\mathrm{S}+0.5 \mathrm{Cl})$ ratio. The dechlorination ratio is less than the desulfuration ratio. It is even less than $80 \%$ when the $\mathrm{Ca} /$ $(\mathrm{S}+0.5 \mathrm{Cl})$ ratio attains 4.5 .

Figures 14 and 15 indicate $\mathrm{CO}$ and $\mathrm{NO}$ concentration with increasing $\mathrm{Ca} /(\mathrm{S}+0.5 \mathrm{Cl})$ ratio. Calcium addition significantly depresses $\mathrm{CO}$ emission, while it only slightly reduces NO emission. With increasing $\mathrm{Ca} /(\mathrm{S}+0.5 \mathrm{Cl})$ ratio, $\mathrm{CO}$ emission quickly decreases. When the $\mathrm{Ca} /(\mathrm{S}+0.5 \mathrm{Cl})$ ratio attains 2.5 , $\mathrm{CO}$ emission attains at the minimum and then almost stays stable. As compared to $\mathrm{CO}$ emission, $\mathrm{NO}$ emission decreases slightly and steadily with increasing $\mathrm{Ca} /(\mathrm{S}+0.5 \mathrm{Cl})$ ratio.

\section{Discussion}

Effect of Chlorine Origin and Temperature on Gaseous Chlorine Species. Normally, the origin of chlorine in RDF or coal might be separated as organic and inorganic chlorine. In coal, the chlorine exists mainly as the "semi-organic" $\mathrm{Cl}$ : anion $\mathrm{Cl}^{-}$, which is sorbed on the coal organic surface in pores and being surrounding by pore moisture. ${ }^{24}$ In $\mathrm{RDF}$, inorganic chlorine $(\mathrm{NaCl}$, etc.) and organic chlorine (PVC, etc.) exist

(24) Yudovich, Y. E.; Ketris, M. P. Chlorine in coal: a review. Int. J. Coal Geol. 2006, 67, 127-144. 


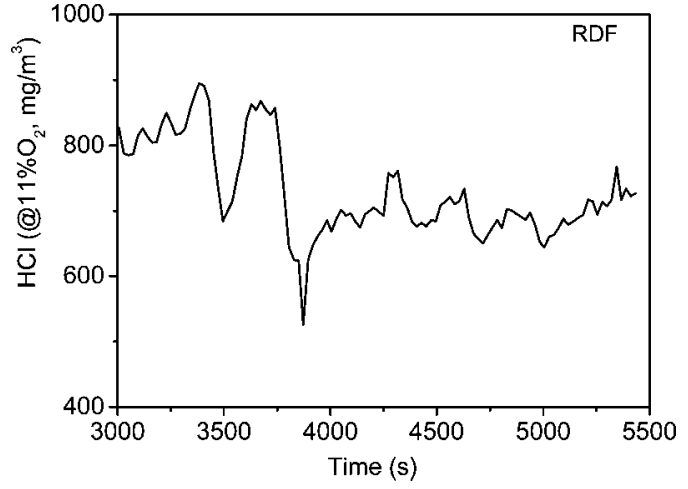

Figure 3. $\mathrm{HCl}$ emission with varied time during pure RDF combustion.

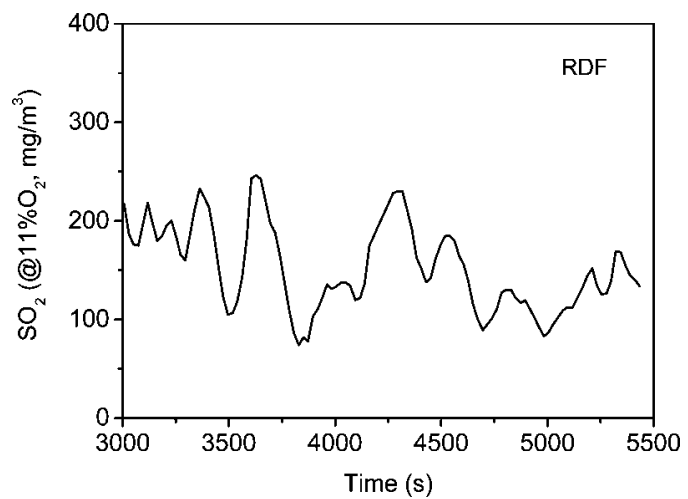

Figure 4. $\mathrm{SO}_{2}$ emission with varied time during pure RDF combustion.

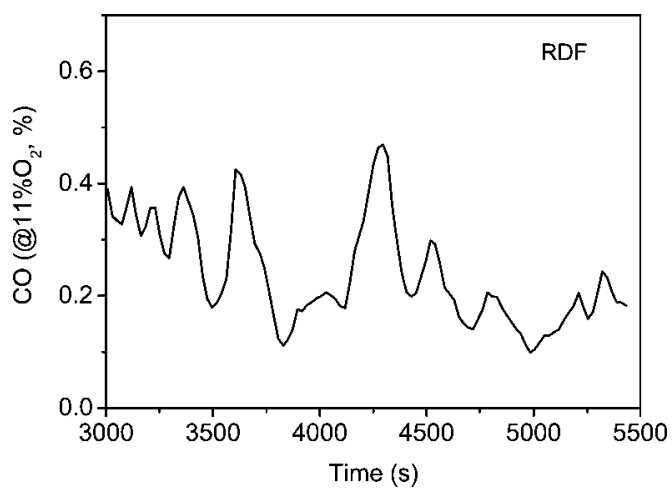

Figure 5. CO emission with varied time during pure RDF combustion.

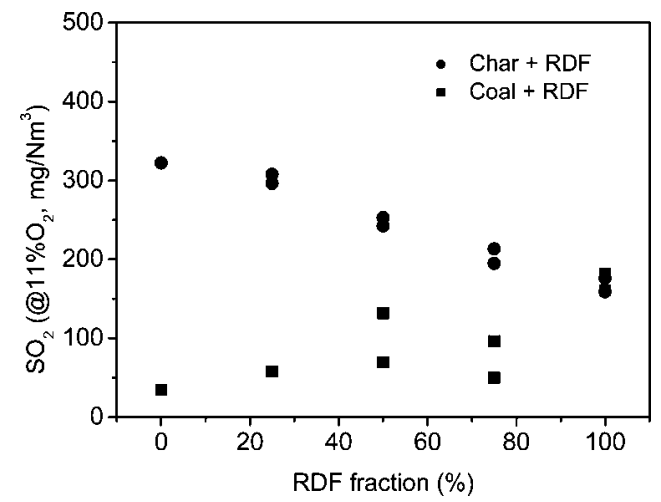

Figure 6. Release of $\mathrm{SO}_{2}$ during cocombustion with various $\mathrm{RDF}$ fractions.

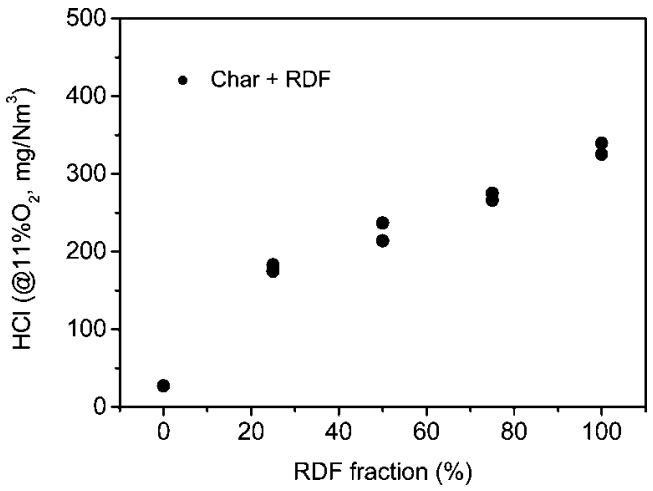

Figure 7. Release of $\mathrm{HCl}$ during cocombustion with various $\mathrm{RDF}$ fractions.

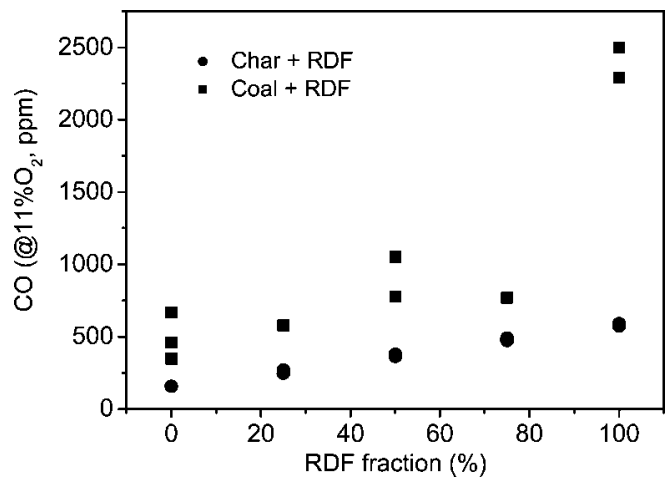

Figure 8. Release of $\mathrm{CO}$ during cocombustion with various RDF fractions.

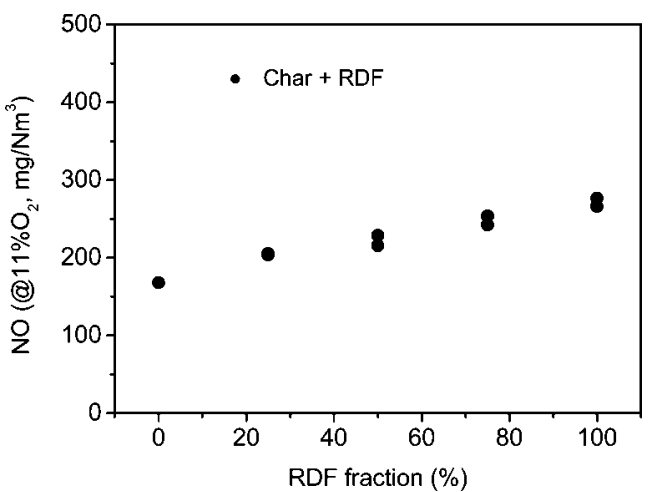

Figure 9. Release of NO during cocombustion with various RDF fractions.

together. The origin of chlorine in fuel may play a role in the release of chlorine during combustion.

The release of chlorine is also dependent on the bed temperature. At high temperature, besides $\mathrm{HCl}(\mathrm{g}), \mathrm{KCl}(\mathrm{g})$ and $\mathrm{NaCl}(\mathrm{g})$ might be released. Also, in the cooling process gaseous $\mathrm{NaCl}$ and $\mathrm{KCl}$ will condense on the furnace wall as solid salts, which can cause fouling, slagging, and corrosion in the furnace. ${ }^{14,15}$ However, during the experiments, only $\mathrm{HCl}(\mathrm{g})$ might be measured by the FTIR. To analyze the release of gaseous $\mathrm{HCl}, \mathrm{KCl}$, and $\mathrm{NaCl}$, the chemical equilibrium calculation is used to predict the effect of different origins on released species of chlorine and the species distribution under various temperatures.

(25) Xie, W.; Liu, K.; Pan, W.-P.; Riley, J. T. Interaction between emissions of $\mathrm{SO}_{2}$ and $\mathrm{HCl}$ in fluidized bed combustors. Fuel 1999, 78, 14251436.

(26) Halstead, W. D.; Raask, E. The behavior of sulfur and chlorine compounds in pulverized-coal-fired boilers. J. Inst. Fuel 1969, 42, 344-349. 


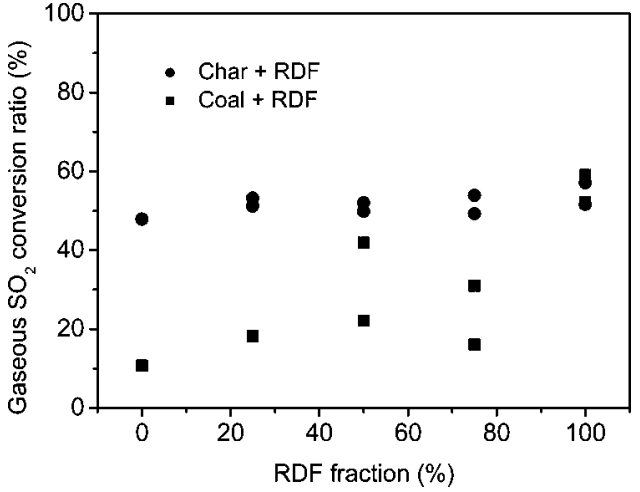

Figure 10. Gaseous $\mathrm{SO}_{2}$ conversion ratio during cocombustion with various $\mathrm{RDF}$ fractions.

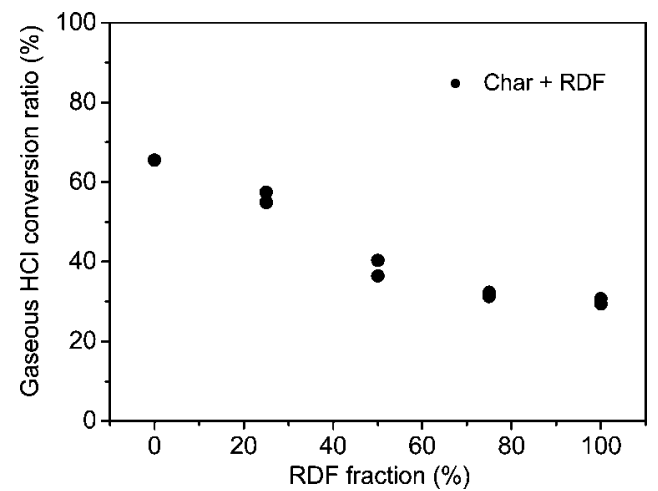

Figure 11. Gaseous $\mathrm{HCl}$ conversion ratio during cocombustion with various RDF fractions.

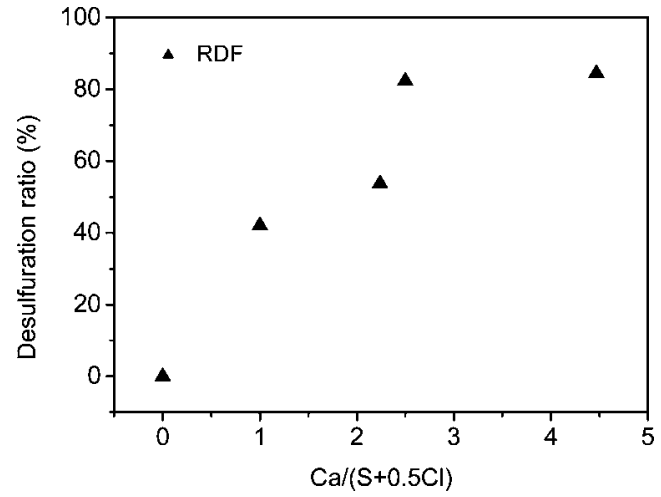

Figure 12. Desulfuration ratio with $\mathrm{CaO}$ addition during pure $\mathrm{RDF}$ combustion.

The chemical equilibrium calculation software FactSage 5.2 is used to predict the gaseous formation, which is based on the Gibbs free energy minimization approach. There are mainly two databases included in the software: FACT (compound database, over 4400 compounds) and ELEM (elements database, 90 elements). In the paper, for the system including elements $\mathrm{C}, \mathrm{H}, \mathrm{O}, \mathrm{N}, \mathrm{S}, \mathrm{Cl}, \mathrm{Si}, \mathrm{P}, \mathrm{Ca}, \mathrm{K}, \mathrm{Na}, \mathrm{Mg}$, $\mathrm{Al}, \mathrm{Fe}, \mathrm{Ti}$, and $\mathrm{Mn}$ between 400 and $1800 \mathrm{~K}$, there are 611 compounds (143 gas, 94 liquid, and 374 solid compounds) selected. The 99 main compounds (44 gaseous and 55 condensed compounds) from the calculating results are shown in Table 3. During the calculation, the excess air ratio remains at 1.6 , and the coal/RDF ratio means the mass ratio. The effects of chlorine origin, temperature, and varied coal/RDF ratio are studied.

Polyvinyl chloride (PVC) and salt $(\mathrm{NaCl})$ are assumed as the organic and inorganic origins of chlorine in RDF, respectively. Figure 16 gives the release ratio of chlorine in $\mathrm{PVC}$ and $\mathrm{NaCl}$

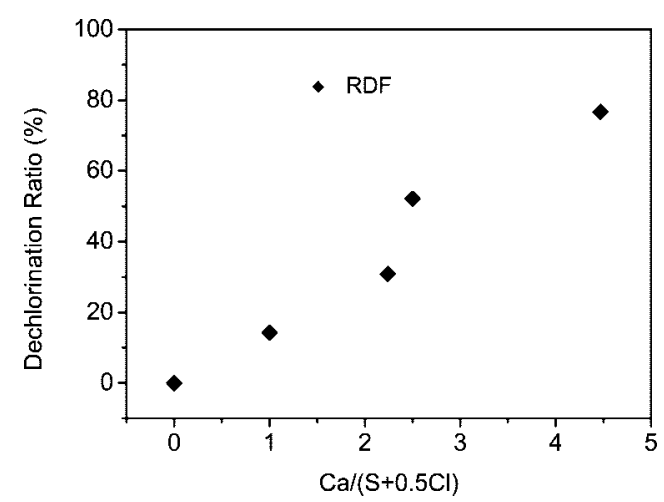

Figure 13. Dechlorination ratio with $\mathrm{CaO}$ addition during pure $\mathrm{RDF}$ combustion.

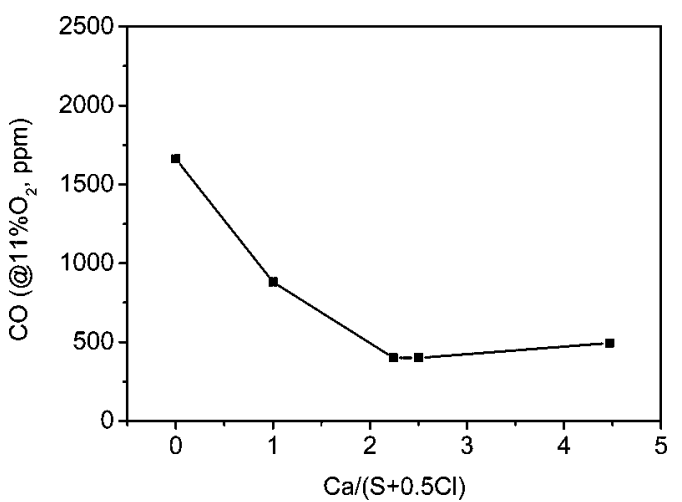

Figure 14. $\mathrm{CO}$ concentration with various $\mathrm{Ca} /(\mathrm{S}+0.5 \mathrm{Cl})$ ratio.

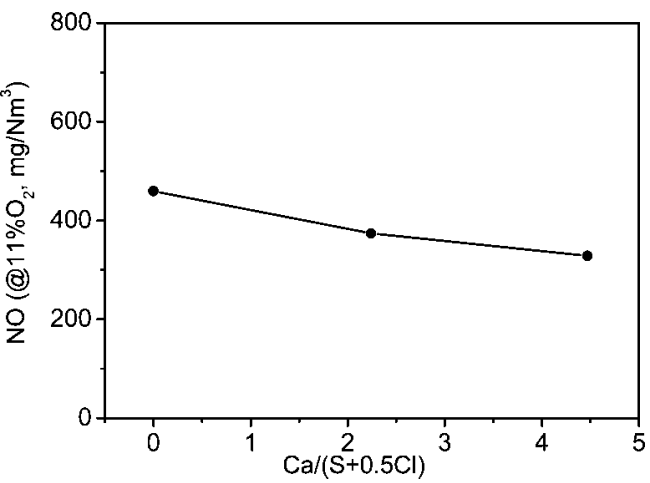

Figure 15. $\mathrm{NO}$ concentration with various $\mathrm{Ca} /(\mathrm{S}+0.5 \mathrm{Cl})$ ratio.

during combustion under various temperatures. In Figure 16a, almost all of chlorine from $\mathrm{PVC}$ is released as gaseous $\mathrm{HCl}$ at the range of bed temperatures $(1073-1173 \mathrm{~K})$. Some of the chlorine is released as $\mathrm{Cl}_{2}$, especially in the lower temperature. In Figure 16b, only a very small amount of chlorine from $\mathrm{NaCl}$ is released. The calculating results indicate that the release of $\mathrm{HCl}$ from organic chlorine is more dependent on the combustion temperature than that from inorganic chlorine. At the bed temperatures, organic chlorine is released more easily.

Under lower temperature, $\mathrm{Cl}_{2}$ may form via a reaction known as the Deacon reaction: ${ }^{25}$

$$
2 \mathrm{HCl}+\frac{1}{2} \mathrm{O}_{2} \leftrightarrow \mathrm{H}_{2} \mathrm{O}+\mathrm{Cl}_{2}
$$

This may occur in the gas cooling process. Molecular chlorine may play an important role in the formation of dioxin. ${ }^{20}$ On the other hand, $\mathrm{SO}_{2}$ may be attacked by $\mathrm{Cl}_{2}$ to form $\mathrm{SO}_{3}$ and $\mathrm{HCl}:{ }^{25}$

$$
\mathrm{Cl}_{2}+\mathrm{SO}_{2}+\mathrm{H}_{2} \mathrm{O} \leftrightarrow 2 \mathrm{HCl}+\mathrm{SO}_{3}
$$




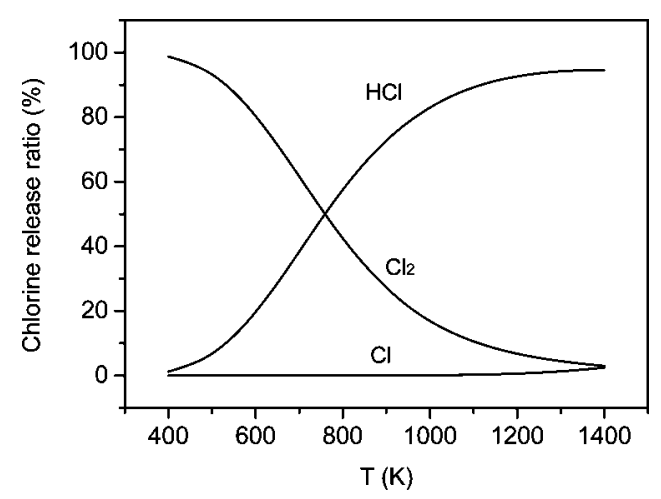

(a) PVC

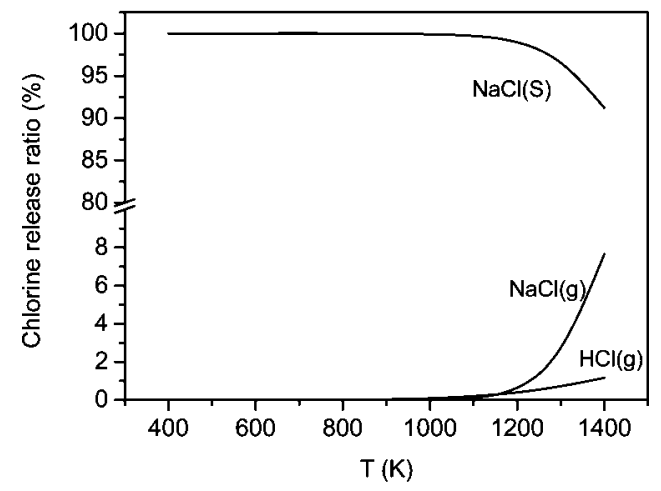

(b) $\mathrm{NaCl}$

Figure 16. Distribution of the released chlorine species from PVC and $\mathrm{NaCl}$ during combustion.

This will decrease the formation of molecular chlorine. It indicates that the sulfur presence could suppress dioxin formation.

Figure 17a,b indicates the effect of temperature on gaseous release of $\mathrm{HCl} / \mathrm{NaCl} / \mathrm{KCl}$ with various conditions. Although $\mathrm{Cl}$ and $\mathrm{Cl}_{2}$ are also two important species containing chlorine, the results show that their concentrations are over one magnitude smaller than that of $\mathrm{HCl} / \mathrm{NaCl} / \mathrm{KCl}$, and they are not shown in the figures. It indicates that the existence of $\mathrm{SO}_{2}$ will result in less formation of $\mathrm{Cl}$ and $\mathrm{Cl}_{2}$. In Figure $17 \mathrm{a}$, it can be seen that the release of $\mathrm{HCl}$ remains nearly stable during 500 and $1200 \mathrm{~K}$ when the coal is burned. In Figure $17 \mathrm{~b}$, when cofiring coal and RDF, the gaseous $\mathrm{HCl}$ concentration increases quickly and then decreases sharply, and the maximum concentration of $\mathrm{HCl}$ is attained at about $900 \mathrm{~K}$. Gaseous $\mathrm{NaCl}$ and $\mathrm{KCl}$ begin to release from about $900 \mathrm{~K}$. In the practical $\mathrm{FBC}$ furnace, the gaseous $\mathrm{NaCl}$ and $\mathrm{KCl}$ release from the dense phase zone. Once temperature decreases along the bed height, $\mathrm{NaCl}$ and $\mathrm{KCl}$ will adhere to the furnace wall as solid salts, which perhaps erode the metal wall. Thus, the release of gaseous alkali metal should be controlled during combustion.

Considering that the temperature in the dense phase zone is $1123-1173 \mathrm{~K}$ in the tests, $1150 \mathrm{~K}$ is chosen as the reaction temperature for calculation to study the formation of $\mathrm{SO}_{2} /$ $\mathrm{HCl} / \mathrm{NaCl} / \mathrm{KCl}$ in the furnace, and the results are shown in Figure 18. During cofiring coal and RDF, with increasing RDF content, gaseous $\mathrm{NaCl}$ and $\mathrm{KCl}$ increase steadily. In pure RDF combustion, the fraction of chlorine release as $\mathrm{NaCl}$ and $\mathrm{KCl}$ nearly approaches that of $\mathrm{HCl}$.

Release of $\mathrm{HCl}$ and Its Retention by Additional CaO. The results of Figure 11 may be explained by the origin and content of chlorine, sulfur, and alkaline metals in coal or RDF. During RDF combustion in ICFB, the chlorine from

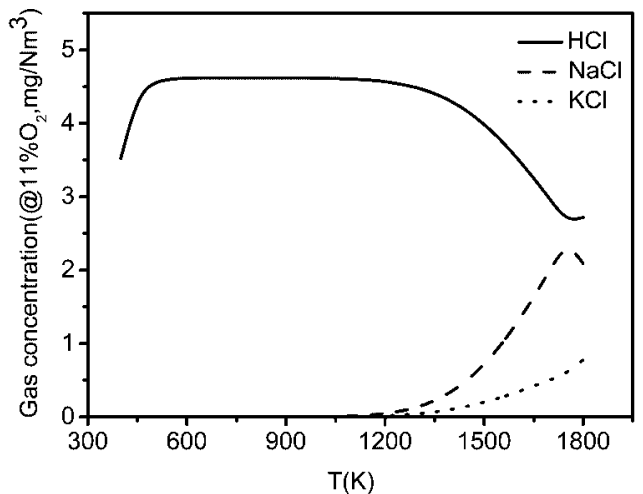

(a) Pure coal

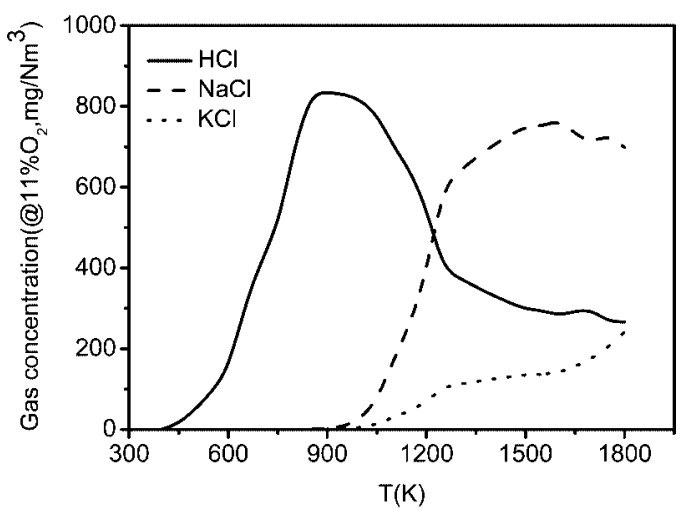

(b) $50 \% \mathrm{coal}+50 \% \mathrm{RDF}$

Figure 17. Distribution of the released chlorine species from cofiring coal and RDF.

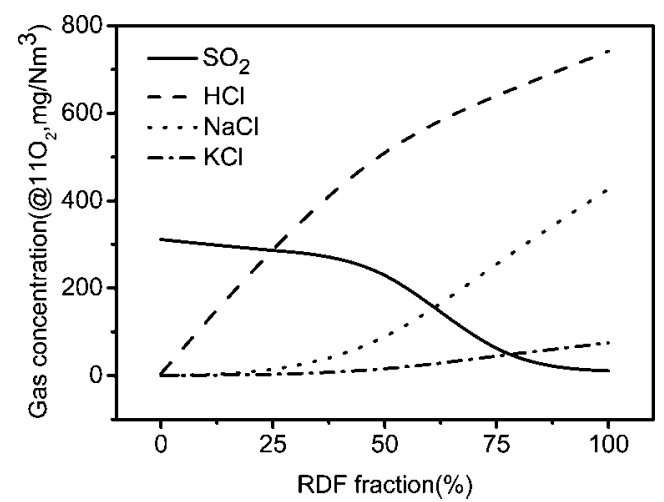

Figure 18. Distribution of the released chlorine species from cofiring coal and RDF at $1150 \mathrm{~K}$.

PVC is released more easily as $\mathrm{HCl}$. Also, $\mathrm{NaCl}$ in fuel may induce the following reaction: ${ }^{26,27}$

$$
\begin{aligned}
& 2 \mathrm{NaCl}(\text { liq })+ \mathrm{SO}_{2}(\mathrm{~g})+\mathrm{H}_{2} \mathrm{O}(\mathrm{g})+ \\
& 0.5 \mathrm{O}_{2}(\mathrm{~g}) \leftrightarrow \\
& \mathrm{Na}_{2} \mathrm{SO}_{4}(\mathrm{~g})+2 \mathrm{HCl}(\mathrm{g})
\end{aligned}
$$

For cofiring char with RDF ratio less than $25 \%, \mathrm{SO}_{2}$ emission is higher than $\mathrm{HCl}$ emission. The above reaction results in more $\mathrm{HCl}$ emission from the inorganic chlorine. With increasing $\mathrm{RDF}$ ratio, $\mathrm{SO}_{2}$ emission deceases and $\mathrm{HCl}$ emission increases, and thus the above reaction becomes less important and the chlorine might be retained by the reaction: ${ }^{28}$

$$
\mathrm{CaO}(\mathrm{s})+2 \mathrm{HCl}(\mathrm{g}) \leftrightarrow \mathrm{CaCl}_{2}(\mathrm{~s}, \mathrm{l})+\mathrm{H}_{2} \mathrm{O}(\mathrm{g})
$$

Obviously, the gaseous $\mathrm{HCl}$ conversion ratio is determined by the chlorine content and origin as well as the competition between reactions 3 and 4 . The change of gaseous $\mathrm{SO}_{2}$ conversion ratio might be explained by these factors, but is 
Table 3. Main Species Used in the Thermodynamic Equilibrium Calculation

\begin{tabular}{|c|c|}
\hline category & species \\
\hline condensed species (55) & $\begin{array}{l}\mathrm{O}_{2}, \mathrm{OH}, \mathrm{H}_{2} \mathrm{O}, \mathrm{CO}, \mathrm{CO}_{2}, \mathrm{Na}, \mathrm{NaO}, \mathrm{NaOH},(\mathrm{NaOH})_{2}, \mathrm{SO}, \mathrm{SO}_{2}, \mathrm{SO}_{3}, \\
\mathrm{O}_{2} \mathrm{~S}(\mathrm{OH})_{2}, \mathrm{Na}_{2} \mathrm{SO}_{4}, \mathrm{Cl}, \mathrm{Cl}_{2}, \mathrm{HCl}, \mathrm{ClO}, \mathrm{HOCl}, \mathrm{COCl}, \mathrm{COCl} \\
\end{array}$ \\
\hline
\end{tabular}

more complicated. In addition, sulfur is likely to be absorbed by calcium and magnesium in ash under fluidized bed temperature.

On the other hand, $\mathrm{HCl}$ capture in bed depends very strongly on bed temperature. Reaction 4 is strongly reversible at typical FBC conditions. ${ }^{29}$ Actually, $\mathrm{HCl}$ capture will be very limited at normal bed temperatures. In addition, $\mathrm{CaCl}_{2}$ may also react with $\mathrm{SO}_{2}$ via the reactions:

$$
\begin{gathered}
\mathrm{CaCl}_{2}+\mathrm{SO}_{2}+\mathrm{O}_{2} \leftrightarrow \mathrm{CaSO}_{4}+\mathrm{Cl}_{2} \\
\mathrm{CaCl}_{2}+\mathrm{SO}_{2}+\mathrm{H}_{2} \mathrm{O} \leftrightarrow \mathrm{CaSO}_{4}+2 \mathrm{HCl}
\end{gathered}
$$

It will induce $\mathrm{HCl}$ and $\mathrm{Cl}_{2}$ to be released again from the bed.

The adsorption of $\mathrm{HCl}$ by additional $\mathrm{CaO}$ can be described by reaction 4 , which is significantly dependent on the temperature. As temperature increases, the chlorination of $\mathrm{CaO}$ goes through a maximum at around $873 \mathrm{~K} .{ }^{30}$ With increasing the temperature to $1073-1173 \mathrm{~K}$ (at FBC state), relatively little adsorption may be possible. For example, at $1073 \mathrm{~K}$ only $30 \%$ conversion of the limestone was reported. ${ }^{31}$ Obviously, the adsorption is limited by chemical equilibrium between gas and solid. In the results of Figures 12 and 13, the dechlorination ratio is less than the desulfuration ratio, especially for the lower $\mathrm{Ca} /(\mathrm{S}+0.5 \mathrm{Cl})$. When $\mathrm{Ca} /(\mathrm{S}+0.5 \mathrm{Cl})$ is higher than 4 , the dechlorination ratio rises to about $80 \%$. This may be explained by the adsorption in freeboard. When more $\mathrm{CaO}$ is added, some of pulverized $\mathrm{CaO}$ may flow into the freeboard, where the adsorption may occur preferably because of relatively low temperature.

Effect of Additional $\mathrm{CaO}$ and $\mathrm{HCl}$ on $\mathrm{CO}$ and NO Emission. There are two factors that might have influences

(27) Wei, X. L.; Lopez, C.; von Puttkamer, T.; Schnell, U.; Unterberger, S.; Hein, K. R. G. Assessment of chlorine-alkali-mineral interactions during co-combustion of coal and straw. Energy Fuels 2002, 16, 1095-1108.

(28) Partanen, J.; Peter Backman, P.; Backman, R.; Hupa, M. Absorption of $\mathrm{HCl}$ by limestone in hot flue gases. Part I: the effects of temperature, gas atmosphere and absorbent quality. Fuel 2005, 84, 1664-1673.

(29) Zhang, C. X.; Wang, Y. X.; Yang, Z. H.; Xu, M. H. Chlorine emission and dechlorination in co-firing coal and the residue from hydrochloric acid hydrolysis of discorea zingiberensis. Fuel 2006, 85, 2034 2040.

(30) Lawrence, A. D.; Bu, J. The reactions between Ca-based solids and gases representative of those found in a fluidized-bed incinerator. Chem. Eng. Sci. 2000, 55, 6129-6137.

(31) Weinell, C. E.; Jensen, P. I.; Dam-Johansen, K.; Livbjerg, H. Hydrogen chloride reaction with lime and limestone: Kinetics and sorption capacity. Ind. Eng. Chem. Res. 1992, 31, 164-171. on $\mathrm{NO}$ and $\mathrm{CO}$ emission when adding $\mathrm{CaO}$. One is the catalysis of $\mathrm{CaO}$ and char on the reaction of $\mathrm{NO}$ and $\mathrm{CO}$ as follows: ${ }^{32}$

$$
\begin{aligned}
& \mathrm{NO}+\mathrm{CO} \stackrel{\mathrm{CaO}}{\longrightarrow} \frac{1}{2} \mathrm{~N}_{2}+\mathrm{CO}_{2} \\
& \mathrm{NO}+\mathrm{CO} \stackrel{\text { char }}{\longrightarrow} \frac{1}{2} \mathrm{~N}_{2}+\mathrm{CO}_{2}
\end{aligned}
$$

Under the conditions with high CO concentration $(>1000$ ppm), $\mathrm{CaO}$ and char will catalyze the reaction of $\mathrm{NO}$ and $\mathrm{CO}$. Therefore, $\mathrm{CaO}$ addition will reduce $\mathrm{NO}$ and $\mathrm{CO}$ emission. Another factor is the influence of $\mathrm{HCl}$ on the $\mathrm{NO}$ and $\mathrm{CO}$ emission. ${ }^{33-35} \mathrm{HCl}$ may significantly inhibit $\mathrm{CO}$ oxidation to increase $\mathrm{CO}$ emission. Therefore, increasing the $\mathrm{Ca} /(\mathrm{S}+0.5 \mathrm{Cl})$ ratio will reduce $\mathrm{HCl}$ emission and decrease $\mathrm{CO}$ emission (see Figure 14). The influence of $\mathrm{HCl}$ on $\mathrm{NO}$ emission is still not clear. ${ }^{34,35}$ The results of Lu et al. indicate that chlorine increases NO emission in FBC. ${ }^{34}$ Yet Gokulakrishnan and Lawrence found that $\mathrm{HCl}$ addition may reduce $\mathrm{NO}$ formation. ${ }^{35}$ In Figure 15 , it can be seen that the influence of $\mathrm{HCl}$ on $\mathrm{NO}$ emission is not significant and an increasing $\mathrm{Ca} /(\mathrm{S}+0.5 \mathrm{Cl})$ ratio slightly decreases $\mathrm{NO}$ emission.

\section{Conclusions}

The release of chlorine and sulfur during the cofiring of RDF and coal is investigated in ICFB. The concentration of $\mathrm{SO}_{2}$, $\mathrm{HCl}$, or $\mathrm{CO}$ significantly varies in pure RDF combustion. Although the sulfur content in RDF is similar to that in coal, the concentration of $\mathrm{SO}_{2}$ is a little less than that in pure RDF combustion. During cofiring RDF and char, the concentration of $\mathrm{HCl}$ approximately linearly varies with increasing $\mathrm{RDF}$ fraction. Because the volatile content in RDF is much higher than that in coal, the $\mathrm{CO}$ concentration gradually increases with increasing RDF fraction.

(32) Johnsson, J. E. A kinetic model for $\mathrm{NO}_{x}$ formation in fluidized bed combustion. Proceedings of the 11th International Conference on Fluidized Bed Combustion; ASME, New York, 1989; pp 1111-1118.

(33) Anthony, E. J.; Bulewicz, E. M.; Janicka, E.; Kandefer, S. Chemical links between different pollutant emissions from a small bubbling FBC. Fuel 1998, 77, 713-728.

(34) Lu, D. Y.; Anthony, E. J.; Talbot, R.; Winter, F.; Löffler, G.; Wartha, C. Understanding of halogen impacts in fluidized bed combustion. Energy Fuels 2001, 15, 533-540.

(35) Gokulakrishnan, P.; Lawrence, A. D. An experimental study of the inhibiting effect of chlorine in a fluidized bed combustor. Combust. Flame 1999, 116, 640-652. 
The release ratio of chlorine and sulfur is mainly dependent on the temperature and alkaline metal in fuel ash. $\mathrm{HCl}$ capture will be very limited at normal bed temperatures and thus may require some other way to control it. With the $\mathrm{CaO}$ addition, the sulfur absorption by calcium quickly increases, and the desulfuration ratio is bigger than the dechlorination ratio. Calcium addition significantly depresses $\mathrm{CO}$ emission, while it only slightly reduces NO emission.

The equilibrium calculations show that organic chlorine is released more easily than is inorganic chlorine at the bed temperatures. Gaseous $\mathrm{HCl}$ emission increases with increasing $\mathrm{RDF}$ fraction, and gaseous $\mathrm{KCl}$ and $\mathrm{NaCl}$ formation might occur from about $900 \mathrm{~K}$.

Acknowledgment. Financial support by the National Natural Science Foundation of China (Project Nos. 50776099 and 50376068) is gratefully acknowledged. We also thank Prof. Qinggang Lu and Yongjie Na as well as Dr. Cheng Qin for their help on this work.

EF800469N 